(This chapter appears in: Alison Park et al, eds, British Social Attitudes: the 18th Report-Public policy, Social ties, London, Sage, 2001, pp199-225).

\title{
Political Engagement, Trust and Constitutional Reform
}

\section{Catherine Bromley, John Curtice and Ben Seyd*}

For many years, critics of Britain's democratic system have argued that it is atrophying. They have claimed that citizens are able to exert only weak control over a system of government that finds it difficult to meet popular needs and demands because of its centralised nature (Barnett, 1993). But in 1997 the Conservative government, whose leader, John Major, had enthused about the traditions and institutions of British life, was replaced by a Labour administration which embraced calls for the reform of many of those same institutions. For example, less than a year before becoming Prime Minister, Tony Blair argued:

Changing the way we govern, and not just changing our government, is no longer an optional extra for Britain. So low is public esteem for politicians and the system we operate that there is now little authority for us to use unless and until we first succeed in regaining it (Blair, 1996).

One of the main weapons in Labour's attempt to restore public confidence in Britain's political system was a programme of constitutional reform. Indeed the implementation of that programme was arguably the most striking characteristic of Mr Blair's first administration. It included the creation of new devolved institutions in Scotland, Wales, Northern Ireland and London, the strengthening of individual rights through a Human Rights Act, the removal of the bulk of

\footnotetext{
* Catherine Bromley is a Senior Researcher at the National Centre for Social Research, Scotland, and is Co-Director of the British Social Attitudes survey series. John Curtice is Head of Research at the National Centre for Social Research, Scotland, Deputy Director of the ESRC Centre for Research into Elections and Social Trends, and Professor of Politics and Director of the Social Statistics Laboratory at Strathclyde University. Ben Seyd is a Senior Research Fellow at the Constitution Unit, University College London.
} 
hereditary peers from the House of Lords and the introduction of new proportional voting systems for both devolved and European elections.

Yet for those who hoped that such reforms would rekindle public confidence and involvement in Britain's democracy, the 2001 election held at the end of Labour's first term was a serious disappointment. After already having been lower in 1997 than at any time since 1935, turnout fell by another 12 points to its lowest level since 1918. ${ }^{1}$ A little under three in five people in Great Britain (59.1 per cent) voted. Turnout also fell to record low levels in the local and European elections held between 1998 and 2000. It appears that Britain faces a crisis of confidence and participation that is far deeper than any programme of constitutional reform is capable of reversing.

This chapter examines whether this is really the case. We do so in three stages. First, we examine trends in attitudes towards the political system and in political participation in a broad sense - from voting to signing a petition or going on a demonstration. Next, we consider public attitudes towards Labour's programme of constitutional reform and the impact this appears to have had on attitudes towards the political system. Finally, we examine whether long-term changes in British society are undermining confidence in the political system in a way that Labour's programme of constitutional reform could not hope to address.

\section{Is there a 'crisis' of participation in Britain?}

Our first question is whether the low turnout at recent elections is symptomatic of a wider public malaise with Britain's political system. This might take one of two forms. On the one hand, people may be losing interest in politics and, consequently, becoming not only less likely to vote but also less likely to take part in other forms of political participation. On the other hand, people may still be interested in politics, but no longer believe that the political system responds to such a conventional activity as voting. As a result, they may have become more inclined to engage in 'unconventional' political activities such as going on protests and demonstrations (Dalton, 1999; Fuchs and Klingemann, 1995; Marsh, 1977). After all, the last few years have been marked by notable examples of these sort of protests, ranging from the anti-globalisation protesters at the 2001 G8 summit in Genoa to the coalition of farmers and lorry drivers who brought many parts of Britain to a near standstill in 2000 in protest against high fuel prices.

There are two ways we can examine whether either of these suppositions is correct. First, we can look at what actions people say they would take if parliament were considering a law that they thought was "really unjust and harmful". Second, we can examine the actions that people say they have ever taken in response to what they thought was an unjust and harmful government action. The advantage of the former measure is that it gives us an indication of people's current reported propensity to engage in politics (and so should be sensitive to any changes in willingness to participate over time). Its disadvantage of course is that it does not measure actual participation. The latter measure does measure this, but as it asks people to report any actions they have 
taken over their lifetime, the figures that it generates will be less immediately responsive to changes in people's willingness to participate.

The next table shows recent trends in reported willingness to engage in various forms of political activity. Two points stand out. First, there is no evidence at all of a decline in people's reported willingness to engage. The proportion saying now that they would not do anything in response to an unjust law has barely changed at all across the years. In fact, the number of actions that people say they are willing to undertake has actually tended to increase over time. True, at 32 per cent, the proportion who say they would take three or more actions is a little lower now than it was in 1998 (when 37 per cent said they would do this), but both figures are well above the 14 per cent who named this many actions in 1983 or even the 25 per cent who did so in 1986. Second, while the proportion saying they would go on a protest or a demonstration is now twice what it was in 1983, much of that increase had in fact occurred by the beginning of the 1990s. Since then there has been no consistent increase in reported willingness to engage in this sort of activity. Indeed the one and only apparently consistent change in what people say they are prepared to do is to contact the media, a reflection perhaps of the media's greater interest in audience participation (Davis and Curtice, 2000).

Table 1 Potential political action, 1983-2000

\begin{tabular}{|c|c|c|c|c|c|c|c|}
\hline$\%$ saying they would & 1983 & 1986 & 1989 & 1991 & 1994 & 1998 & 2000 \\
\hline Sign a petition & 55 & 65 & 71 & 78 & 67 & 67 & 68 \\
\hline Contact their MP & 46 & 52 & 54 & 48 & 58 & 59 & 50 \\
\hline $\begin{array}{l}\text { Contact radio, TV or } \\
\text { newspaper }\end{array}$ & 14 & 15 & 14 & 14 & 21 & 21 & 22 \\
\hline $\begin{array}{l}\text { Go on a protest or } \\
\text { demonstration }\end{array}$ & 8 & 11 & 14 & 14 & 16 & 21 & 16 \\
\hline $\begin{array}{l}\text { Speak to an influential } \\
\text { person }\end{array}$ & 10 & 15 & 15 & 17 & 14 & 18 & 17 \\
\hline $\begin{array}{l}\text { Contact a government } \\
\text { department }\end{array}$ & 7 & 12 & 12 & 11 & 14 & 17 & 14 \\
\hline $\begin{array}{l}\text { Form a group of like- } \\
\text { minded people }\end{array}$ & 6 & 8 & 10 & 7 & 10 & 9 & 7 \\
\hline $\begin{array}{l}\text { Raise the issue in an } \\
\text { organisation they already } \\
\text { belong to }\end{array}$ & 9 & 10 & 11 & 9 & 7 & 9 & 10 \\
\hline None of these & 13 & 10 & 8 & 6 & 7 & 7 & 7 \\
\hline Base & 1761 & 1548 & 1516 & 1445 & 1137 & 2030 & 2293 \\
\hline
\end{tabular}

Looking at what people say they have done as opposed to what they say they would do confirms that there has been no decline in overall levels of political 
participation. In our most recent survey, just over half say that they have undertaken at least one action in response to a government action they considered unjust and harmful. In 1994, when we last asked this question, the figure was a little under a half, as it was in 1986 when we first asked it. Indeed, the proportion who claim to have taken three or more actions has slowly but consistently risen from five per cent in 1986 to nine per cent now.

Nor is there much sign of change in the kinds of political activity in which people engage. Few have ever taken part in significant time-consuming activity, but then it has always been thus. Signing a petition remains by far and away the most common form of non-electoral participation, a relatively undemanding and perhaps fleeting activity. However, we can see that there has been a small but consistent increase over time in the proportion of people who have been on a protest or a demonstration. So perhaps here we do have a sign that there has been some increase at least in more unconventional forms of political activity that might reflect frustration with the conventional workings of democracy.

But one further piece of evidence casts doubt upon this interpretation. For the most part people engage in these unconventional forms of political participation as well as, rather than instead of, voting. Thus, 87 per cent of those who had ever been on a protest or a demonstration said they voted in the 1997 general election, compared with only 71 per cent of those who had not been on a protest. When it comes to voting in the 1999 European election, the equivalent figures are 50 per cent and 36 per cent respectively. Similar differences are found in relation to all of the other activities in the following table. So there does not appear to be a wholesale shift away from the ballot box to the streets.

Table 2 Actual political action, 1986-2000

\begin{tabular}{lrrrrr}
\hline \% saying they had & $\mathbf{1 9 8 6}$ & $\mathbf{1 9 8 9}$ & $\mathbf{1 9 9 1}$ & $\mathbf{1 9 9 4}$ & $\mathbf{2 0 0 0}$ \\
Signed a petition & 34 & 41 & 53 & 39 & 42 \\
Contacted their MP & 11 & 15 & 17 & 14 & 16 \\
Contacted radio, TV or newspaper & 3 & 4 & 4 & 5 & 6 \\
Gone on a protest or demonstration & 6 & 8 & 9 & 9 & 10 \\
$\quad$ Spoken to an influential person & 1 & 3 & 5 & 3 & 4 \\
Contacted a government department & 3 & 3 & 4 & 3 & 4 \\
Formed a group of like-minded people & 2 & 3 & 2 & 3 & 2 \\
Raised the issue in an organisation they & & & & & \\
$\quad$ already belong to & 5 & 4 & 5 & 4 & 5 \\
None of these & 56 & 48 & 37 & 53 & 47 \\
Base & 1548 & 1516 & 1445 & 1137 & 2293 \\
\hline
\end{tabular}




\section{Confidence in the political system}

These findings suggest that recent low election turnouts do not appear to be symptomatic of a wider malaise. There is little evidence that other forms of political participation are in decline or that people are resorting to such activities instead of voting. ${ }^{2}$ If anything, the opposite is the case. Perhaps, after all, people are reasonably content with the way that their democracy is working?

We can assess this in two ways. First we consider how much trust people have in key political institutions and sets of actors. Then we examine "political efficacy', that is the confidence that people have in their ability to articulate demands effectively and in the ability of the political system to respond to them. According to Almond and Verba (1963), a democracy requires a balance of efficacy and trust amongst its citizens in order to perform effectively. They need to feel that they can make their views known when necessary, but they should be equally willing to trust their rulers to make the right decisions most of the time.

In truth, we are not (and never have been) very trustful of governments and politicians. As the next table shows, only around one in ten of us trust politicians of any party to tell the truth when they are in a tight corner "just about always" or "most of the time", a figure that has not changed at all in recent years. However there has been a clear change of mood when it comes to our willingness to trust governments to put the needs of the nation above the interests of their own party. Up to (and including) 1991 at least one in three of us trusted governments to do this at least most of the time. But during the 1990s there was a gradual erosion of that trust and now only one in six, a new all time low, take this view of government. True, there appeared to be something of a recovery in the immediate wake of Labour's election victory in 1997 (as registered by our 1998 survey), but this appears to have been only a temporary halt.

Politicians cannot blame this apparently growing cynicism about their motives on any increasing tendency amongst the electorate simply to distrust all those in authority. As the following table also shows, there has been no equivalent growing distrust of either the police or civil servants. Indeed we now appear to be more trustful of both of these than we were for much of the 1990s, with the police in particular having apparently been particularly successful at recapturing public confidence. Almost three in five of us now trust them not to bend the rules to try and get a conviction. 
Table 3 Trends in political trust, $1974-2000$

\begin{tabular}{|c|c|c|c|c|c|c|c|}
\hline $\begin{array}{l}\text { \% who trust the following } \\
\text { "just about always" or "most } \\
\text { of the time" }\end{array}$ & 1974 & 1987 & 1991 & 1994 & 1996 & 1998 & 2000 \\
\hline $\begin{array}{l}\text { British governments of any } \\
\text { party to place the needs of } \\
\text { the nation above the } \\
\text { interests of their own political } \\
\text { party }\end{array}$ & 39 & 37 & 33 & 24 & 22 & 29 & 16 \\
\hline $\begin{array}{l}\text { Politicians of any party to tell } \\
\text { the truth when they are in a } \\
\text { tight corner }\end{array}$ & - & - & - & 9 & 9 & 9 & 11 \\
\hline $\begin{array}{l}\text { British police not to bend the } \\
\text { rules in trying to get a } \\
\text { conviction }\end{array}$ & - & 52 & 49 & 47 & 51 & 48 & 59 \\
\hline $\begin{array}{l}\text { Top civil servants to stand firm } \\
\text { against a minister who wants } \\
\text { to provide false information } \\
\text { to parliament }\end{array}$ & - & 46 & - & 27 & 28 & - & 35 \\
\hline Base & 1802 & 1410 & 1445 & 1137 & 1180 & 2071 & 2293 \\
\hline
\end{tabular}

Source: 1974: Political Action Study. 1987 figure for civil servants: British Election Study 1987 (Base = 3414).

So on our first measure at least it appears that confidence in the workings of our representative democracy has declined, and that far from being reversed during Labour's first term, has eroded even further. But what happens when we look at our second measure, political efficacy? Here we should draw a distinction between two aspects of efficacy. On the one hand, the public will have views about the ability and willingness of the political system to respond to any demands they may make. We refer to this as 'system efficacy'. On the other hand, people will have more or less confidence in their own ability to express demands. This we term 'personal efficacy'. While at any one time those who feel personally efficacious also tend to be those who feel that the system is efficacious (Pattie and Johnston, 2001a), this does not necessarily mean that trends in personal and system efficacy should parallel each other over time. Rather, if it is the case that people have lost confidence in the political system then we might well expect to find that system efficacy has declined while personal efficacy has remained the same or even increased.

As in the case of trust, we have to bear in mind that a considerable degree of scepticism has always existed. Clear majorities have always agreed with each of the indicators of system and personal efficacy in the next two tables. So, to identify whether levels of efficacy have declined, we look just at those who strongly agree with each of the statements. 
Table 4 Trends in system efficacy, 1974-2000

\begin{tabular}{|c|c|c|c|c|c|c|c|}
\hline$\%$ strongly agree & 1974 & 1987 & 1991 & 1994 & 1996 & 1998 & 2000 \\
\hline $\begin{array}{l}\text { Parties are only interested in } \\
\text { people's votes, not in their } \\
\text { opinions }\end{array}$ & 19 & 15 & 16 & 25 & 28 & 21 & 26 \\
\hline $\begin{array}{l}\text { Generally speaking, those we } \\
\text { elect as MPs lose touch with } \\
\text { people pretty quickly }\end{array}$ & 19 & 16 & 16 & 25 & 26 & 20 & 23 \\
\hline $\begin{array}{l}\text { It doesn't really matter which } \\
\text { party is in power, in the end } \\
\text { things go on much the same }\end{array}$ & - & - & 11 & 16 & 16 & 17 & 19 \\
\hline $\begin{array}{l}\text { MPs don't care much about } \\
\text { what people like me think }\end{array}$ & - & - & - & - & 15 & - & 14 \\
\hline Base & 1802 & 1410 & 1445 & 1137 & 1180 & 2071 & 2293 \\
\hline
\end{tabular}

Source: 1974: Political Action Study. In that study respondents were given a four-point scale ranging from "strongly agree" to "strongly disagree". In the subsequent British Social Attitudes studies answers were given on a five-point scale with a mid-point labelled "neither agree nor disagree".

The picture revealed by the previous table is clear. As in the case of political trust, levels of system efficacy fell in the 1990s, recovered somewhat in the wake of Labour's election in 1997, but have now fallen back to more or less where they were in the mid-1990s. Thus, for example, in 1987 only around one in six strongly agreed that, "parties are only interested in people's votes, not in their opinions", or that "generally speaking those we elect as MPs lose touch with people pretty quickly". But by 1996 just over one in four subscribed to each of these views, and while these figures fell again to around one in five in 1998 , they have now returned to around one in four.

In contrast, for the most part levels of personal efficacy show little or no consistent trend. For instance, the proportion strongly agreeing that "people like me have no say in what the government does" or that politics and government can be too complicated to understand is little different now to what it was when the questions were first asked in the British Social Attitudes survey in 1986.

In short, while there seems to have been little long-term change in people's confidence in their own political abilities, confidence in the political system's ability to respond to public demands does appear to have declined. Moreover, that confidence does not appear to have been restored during Labour's first term of office. 
Table 5 Trends in personal efficacy, 1974-2000

\begin{tabular}{|c|c|c|c|c|c|c|c|}
\hline$\%$ strongly agree & 1974 & 1987 & 1991 & 1994 & 1996 & 1998 & 2000 \\
\hline $\begin{array}{l}\text { People like me have no say } \\
\text { in what the government } \\
\text { does }\end{array}$ & 14 & 20 & 16 & 28 & 24 & 17 & 25 \\
\hline \multicolumn{8}{|l|}{$\begin{array}{l}\text { Voting is the only way } \\
\text { people like me can have }\end{array}$} \\
\hline $\begin{array}{l}\text { any say about how the } \\
\text { government does things }\end{array}$ & 15 & - & 12 & 19 & 15 & 14 & 17 \\
\hline $\begin{array}{l}\text { Sometimes politics and } \\
\text { government seem so }\end{array}$ & & & & & & & \\
\hline $\begin{array}{l}\text { complicated that a person } \\
\text { like me cannot really } \\
\text { understand what is going } \\
\text { on }\end{array}$ & 21 & - & 16 & 22 & 22 & 15 & 18 \\
\hline Base & 1802 & 1410 & 1445 & 1137 & 1180 & 2071 & 2293 \\
\hline
\end{tabular}

Source: 1974: Political Action Study. See also note to table 9.4.

There is one further indication of confidence in government that we can examine. This was first asked by the Kilbrandon Commission on the Constitution in the early 1970s and has been asked periodically by a number of surveys ever since. It reads:

Which of these statements best describes your opinion on the present system of governing Britain?

It works extremely well and could not be improved It could be improved in small ways but mainly works well It could be improved quite a lot It needs a great deal of improvement

Thus the question not only asks people to consider how well the political system is performing but also how much could be done to improve it. Responses to it largely confirm the picture painted by our two other measures. Thus, the proportion believing that the system needs little or no improvement reached an all-time low (with just 22 per cent agreeing) in 1995. The advent of the Labour government then saw a significant revival of confidence with nearly half saying that the system needed little or no improvement in 1998, as high as the figure the Kilbrandon Commission itself found in 1973. But now the figure has fallen again. True it remains above the level it reached in the mid-1990s, but our finding that only 35 per cent think that the system needs little or no improvement suggests that Labour's programme of constitutional reform has 
not had much permanent impact on people's confidence in how they are governed. $^{3}$

Table 6 Trends in evaluations of system of government, 1973-2000

\begin{tabular}{llllllllll}
\hline $\begin{array}{l}\text { \% saying system of } \\
\text { governing Britain } \\
\text { could ... }\end{array}$ & 1973 & 1977 & 1991 & 1995 & 1996 & 1998 & 1999 & 2000 \\
$\begin{array}{l}\ldots \text { not be improved or } \\
\text { could be improved } \\
\text { only in small ways } \\
\text { be improved quite a } \\
\text { lot or a great deal }\end{array}$ & 48 & 34 & 33 & 22 & 35 & 45 & 48 & 35 \\
$\begin{array}{l}\text { Base } \\
\text { nase }\end{array}$ & 4892 & 1410 & 1034 & 1758 & 1180 & 2071 & 1060 & 2293 \\
\hline
\end{tabular}

Sources: 1973: Royal Commission on the Constitution, Memorandum of Dissent, 1973; 1977: Opinion Research Centre Survey; 1991/1995: MORI/Rowntree Trust State of the Nation Survey.

The decline in public confidence during the mid-1990s could have reflected the fact that Britain was then being governed by a government, headed by John Major, which was particularly unpopular and was also mired in allegations of 'sleaze'? But if that were the case then its replacement by a new government, let alone one committed to a programme of constitutional reform, should have been sufficient to restore confidence. And according to each of our three measures that evidently has not been the case; the new Labour government has not, as yet at least, restored the bonds between citizens and their political system. It appears instead that there is a more fundamental crisis of confidence in the political system.

Indeed further confirmation that relatively little has changed under Labour comes from the next table which compares levels of efficacy and trust in 1996 (towards the end of John Major's administration) among people who strongly identified with either the Conservative or Labour parties or with no party at all, with the same groups now. Unsurprisingly, we find that levels of trust and efficacy are for the most part higher among strong Labour identifiers now than they were in 1996 when the Conservatives were in power. Meanwhile the opposite pattern is true of Conservative identifiers. But among those with no party political identity levels of efficacy are just as low now as they were in 1996, and their level of trust in government has plummeted. 
Table 7 Trends in efficacy and trust by party identification, 1996-2000

\begin{tabular}{|c|c|c|c|c|c|c|}
\hline \multirow{3}{*}{$\%$ strongly agree } & \multicolumn{3}{|c|}{1996} & \multicolumn{3}{|c|}{2000} \\
\hline & \multicolumn{3}{|c|}{$\begin{array}{c}\text { Party Identification } \\
\text { Conser- }\end{array}$} & \multicolumn{3}{|c|}{$\begin{array}{c}\text { Party Identification } \\
\text { Conser- }\end{array}$} \\
\hline & Labour & vative & None & Labour & vative & None \\
\hline $\begin{array}{l}\text { Parties are only } \\
\text { interested in votes }\end{array}$ & 33 & 18 & 35 & 19 & 25 & 35 \\
\hline $\begin{array}{l}\text { MPs lose touch too } \\
\text { quickly }\end{array}$ & 34 & 15 & 30 & 19 & 26 & 30 \\
\hline $\begin{array}{l}\text { Doesn't matter who in } \\
\text { power }\end{array}$ & 18 & 7 & 27 & 12 & 15 & 34 \\
\hline $\begin{array}{l}\% \text { who trust govern- } \\
\text { ments always/most } \\
\text { of the time to put } \\
\text { nation's interests first }\end{array}$ & 19 & 34 & 18 & 28 & 19 & 5 \\
\hline Base & 284 & 186 & 110 & 434 & 304 & 308 \\
\hline
\end{tabular}

But are we correct in assuming that a decline in levels of trust and efficacy necessarily represents a crisis for the political system? Should we assume that those with low levels of trust are ready to opt out of the political system? Or might a decline simply indicate a public which is less willing to take elected officials' words for granted, and is keener to scrutinise their activities? After all, such scrutiny may be necessary if the public is to ensure that politicians do what they want them to do, especially in a country where general elections may be as much as five years apart (Hardin, 2000). So, far from wanting to withdraw from democracy might those with low levels of trust and efficacy wish instead to see democracy improved (see also Klingemann, 1999)?

Previous analyses of British Social Attitudes' data have themselves cast some doubt on whether those with low level of trust and efficacy are necessarily less likely to participate in elections (Curtice and Jowell, 1995, 1997). However, other research has identified some relationship between abstention and either trust or efficacy (Heath and Taylor, 1999; Pattie and Johnston, 2001b), although other factors (particularly the perceived distance between the parties and the closeness of the contest) appear to be more important. That there is indeed a link between trust, efficacy and turnout is also supported by analysis of data from our most recent survey. So, for example, 78 per cent of those who trust governments to put the interest of the nation first at least most of the time claim to have voted in the 1997 election, compared with only 62 per cent of those who almost never trust governments. The figures for those with high and low levels of political efficacy are almost identical, ${ }^{4}$ and there are differences of a similar kind in respect of voting in the 1999 European elections too. 
Table 8 Political participation by levels of trust and efficacy

\begin{tabular}{|c|c|c|c|}
\hline \multirow[b]{2}{*}{$\begin{array}{l}\% \text { voted in } 1997 \\
\text { general election } \\
\% \text { voted in } 1999\end{array}$} & \multicolumn{3}{|c|}{$\begin{array}{l}\text { Trust government to put interests of the nation first ... } \\
\begin{array}{l}\ldots \text { just about } \\
\text { always or most of } \quad \ldots \text { only some of } \\
\text { the time }\end{array} \quad \text { the time } \quad \ldots \text { almost never }\end{array}$} \\
\hline & 78 & 76 & 62 \\
\hline $\begin{array}{l}\text { Euro election } \\
\% \text { ever taken }\end{array}$ & 46 & 38 & 29 \\
\hline \multirow[t]{3}{*}{ Base } & 368 & $\begin{array}{r}54 \\
1336\end{array}$ & 566 \\
\hline & \multicolumn{3}{|c|}{ Level of system efficacy } \\
\hline & High & Medium & Low \\
\hline $\begin{array}{l}\% \text { voted in } 1997 \\
\text { general election } \\
\% \text { voted in } 1999\end{array}$ & 85 & 79 & 69 \\
\hline $\begin{array}{l}\text { Euro election } \\
\% \text { ever taken }\end{array}$ & 60 & 44 & 33 \\
\hline political action & 73 & 59 & 49 \\
\hline Base & 99 & 480 & 1345 \\
\hline
\end{tabular}

This apparent change in the relationship between electoral participation and political trust and efficacy suggests that, even if it were not initially the case, declining levels of trust and efficacy are helping to undermine turnout at the ballot box. Perhaps initial disillusionment with the system has relatively little impact on willingness to vote, but more prolonged disillusionment then begins to have an effect on certain types of voters? But even if this is the case, we should be wary on the basis of the evidence presented here of assuming that falling trust and efficacy explain the large drop in turnout between 1997 and 2001. After all, levels of efficacy are no lower now than they were before the 1997 election. And the drop since 1996 in levels of trust in government is insufficient to be able to account for the 12-point drop in electoral participation between 1997 and $2001 .^{5}$

The above table also helps explain why we could find little evidence earlier of a decline in non-electoral participation despite the apparent decline in trust and efficacy. It shows that, while there is a relationship between system efficacy and ever having done anything in response to a government action that was thought to be unjust and harmful, there is no apparent relationship between engaging in non-electoral forms of political participation and trust in government. 
So, the decline in confidence in government that emerged under the last Conservative administration was not reversed during Labour's first term. True, this may have only made a contribution to the decline in turnout at recent elections rather than being principally responsible for it. And there is no evidence of any decline in other forms of political participation. But it does appear that Labour's programme of constitutional reform has, so far at least, failed to reconnect citizens with their politicians. We now turn to addressing why this is the case.

\section{The impact of constitutional change}

Reformers believed that constitutional reform would address grievances that the public have about the way that they are governed. And our own previous work also gave reason to believe that it might have a favourable impact. This is because throughout the 1990s those with lower levels of political trust were, for the most part, more likely to have a favourable view of constitutional reform than those with higher levels of trust (Curtice and Jowell, 1995, 1997). We therefore surmised that perhaps their trust would be restored should constitutional reform be implemented.

But of course, implementing constitutional reform could only help restore public confidence in Britain's system of government if people actually welcome its impact in practice. The next table shows what impact people think four examples of constitutional reform have had on the way that Britain is governed. So far at least, the perception appears to be not much. Reform of the House of Lords, freedom of information, and the creation of the Scottish Parliament and the Welsh Assembly are each judged by a majority to have currently made no difference to the way Britain is run. True, in each case more feel that the reform in question has improved matters rather than made them worse, but with the exception of freedom of information the positive balance is only a small one.

Of course, these figures do not directly address the question of whether constitutional reform has increased trust and efficacy among the general public. Moreover, the fact that trust and efficacy have not risen may reflect other influences which have counteracted any beneficial impact that constitutional reform might have had. To assess this, we can conduct two additional analyses. First, we compare the relationship between political trust and attitudes towards constitutional change in 1996 (before reform was implemented) and 2000 (by which time much of Labour's programme was in place). If reform has had a positive impact we would expect to find that trust and efficacy have risen more among those favouring the constitutional reforms that have been implemented than they have among those who are less favourable. 
Table 9 Evaluations of constitutional reform

\begin{tabular}{|c|c|c|c|c|}
\hline & & \multicolumn{3}{|c|}{$\begin{array}{c}\text { Perceived impact on the way Britain as a whole is } \\
\text { governed ... }\end{array}$} \\
\hline & & $\begin{array}{l}\ldots \text { improved it } \\
\text { a lot/a little }\end{array}$ & $\begin{array}{l}\text {... made no } \\
\text { difference }\end{array}$ & $\begin{array}{c}\text {... made it a } \\
\text { little/ a lot } \\
\text { worse }\end{array}$ \\
\hline $\begin{array}{l}\text { Reforming the House } \\
\text { of Lords }\end{array}$ & $\%$ & 11 & 69 & 8 \\
\hline $\begin{array}{l}\text { Introducing freedom of } \\
\text { information } \\
\text { Creatina the Scottish }\end{array}$ & $\%$ & 25 & 59 & 3 \\
\hline Parliament & $\%$ & 19 & 53 & 13 \\
\hline $\begin{array}{l}\text { Creating the Welsh } \\
\text { Assembly }\end{array}$ & $\%$ & 15 & 56 & 12 \\
\hline Base: 2293 & & & & \\
\hline
\end{tabular}

The following table undertakes this exercise in relation to freedom of information. It does so by looking at people's views about whether the government should have "the right to keep its defence plans secret" or whether they think "the public has a right to know what they are". Of course, the question we examine here does not address the government's freedom of information legislation directly (as it posits a greater freedom than that legislation has put in place). But we might reasonably assume that the 45 per cent who say that the public has the right to know such plans comprises those who would be most committed to the principle of freedom of information. But, if this is the case, then Labour's legislation seems to have done little to raise their confidence in the political system. Rather, their level of trust has fallen just as much as has the confidence of those who think the government has the right to keep its defence plans secret, while their level of efficacy has actually fallen more.

These findings do not apply only in respect of freedom of information; they equally apply to views about Scottish devolution. Thus, despite the advent of the Scottish Parliament in 1999, levels of trust and efficacy fell by more or less the same amount between 1996 and 2000 among those who favour devolution as they did among those who do not think Scotland should have any kind of parliament at all. 
Table 10 Changes in trust and efficacy by views about freedom of information, 1996-2000

\begin{tabular}{|c|c|c|c|c|c|c|}
\hline \multirow{3}{*}{$\begin{array}{l}\text { Attitudes towards } \\
\text { defence plans } \\
\text { Public should normally have }\end{array}$} & \multicolumn{3}{|c|}{$\begin{array}{l}\% \text { trust government just } \\
\text { about always/most of the } \\
\text { time }\end{array}$} & \multicolumn{3}{|c|}{$\%$ medium/high efficacy } \\
\hline & 1996 & 2000 & Change & 1996 & 2000 & Change \\
\hline & 19 & 13 & -6 & 35 & 26 & -9 \\
\hline Base & 521 & 877 & & 521 & 877 & \\
\hline $\begin{array}{l}\text { Government should have } \\
\text { right to keep plans secret }\end{array}$ & 26 & 18 & -8 & 37 & 33 & -4 \\
\hline Base & 614 & 1338 & & 614 & 1338 & \\
\hline
\end{tabular}

Our second way of examining the impact of constitutional reform is to compare what has happened in a part of Great Britain that has experienced high profile constitutional change and another part that has not. The most obvious example is devolution - which has been introduced to a significant extent in Scotland but not in England. If devolution has restored confidence in how Britain is governed we should find more favourable trends in trust and efficacy in Scotland than in England. But, as the next table reveals, trends in both trust and efficacy have almost been identical in Scotland and England over the course of the last three years (for further details see Curtice, 2001, forthcoming).

Table 11 Trust and efficacy in England and Scotland, 1997-2000

\begin{tabular}{|c|c|c|c|c|}
\hline$\%$ strongly agree & & 1997 & 2000 & $\begin{array}{c}\text { Change } \\
97-00\end{array}$ \\
\hline $\begin{array}{l}\text { Parties only interested in votes, not } \\
\text { in opinions }\end{array}$ & $\begin{array}{l}\text { England } \\
\text { Scotland }\end{array}$ & $\begin{array}{l}16 \\
16\end{array}$ & $\begin{array}{l}26 \\
24\end{array}$ & $\begin{array}{r}+10 \\
+8\end{array}$ \\
\hline $\begin{array}{l}\text { It doesn't really matter who's in } \\
\text { power, things go on the same }\end{array}$ & $\begin{array}{l}\text { England } \\
\text { Scotland }\end{array}$ & $\begin{array}{l}8 \\
8\end{array}$ & $\begin{array}{l}19 \\
20\end{array}$ & $\begin{array}{l}+11 \\
+12\end{array}$ \\
\hline $\begin{array}{l}\text { Base: England } \\
\text { Base: Scotland }\end{array}$ & & $\begin{array}{r}2187 \\
756\end{array}$ & $\begin{array}{l}1928 \\
1663\end{array}$ & \\
\hline $\begin{array}{l}\% \text { who trust the Government to put } \\
\text { nation before party "just about } \\
\text { always" or " most of the time" }\end{array}$ & $\begin{array}{l}\text { England } \\
\text { Scotland }\end{array}$ & $\begin{array}{l}34 \\
29\end{array}$ & $\begin{array}{l}17 \\
13\end{array}$ & $\begin{array}{l}-17 \\
-16\end{array}$ \\
\hline $\begin{array}{l}\text { Base: England } \\
\text { Base: Scotland }\end{array}$ & & $\begin{array}{r}2551 \\
882\end{array}$ & $\begin{array}{l}1928 \\
1663\end{array}$ & \\
\hline
\end{tabular}

Sources: 1997 England: British Election Study; 1997 Scotland: Scottish Election Study 1997; 2000 Scotland: Scottish Social Attitudes Survey 2000. 
So it appears that Labour's programme of constitutional reform has indeed done little or nothing so far to increase people's confidence in how they are governed.

But of course our findings may well not represent the public's final word on Labour's programme of constitutional reform. Certainly, advocates of reform might reasonably argue that it will take time for its benefits to become apparent. Indeed, the UK government's freedom of information legislation had not even come into force by the time of our survey. But, by this argument, it is also clear that constitutional reform has not been an immediate remedy for declining trust and efficacy.

Alternatively, advocates of reform might be tempted to argue that its inability to increase people's confidence in government reflects its failure to go far enough. Indeed in its 2001 General Election handbook, the constitutional reform lobby, Charter88, argue that Britain needs a full blown 'Citizens' Constitution' (Holden, 2001). In particular, some point to the fact that Labour has failed to implement the one piece of its constitutional programme that they see as having the most potential impact on the way Britain is governed holding a referendum on whether the House of Commons should be elected by an alternative, more proportional, electoral system.

However, as we have previously argued (Curtice and Jowell, 1995), it is far from clear that electoral reform is sufficiently popular for the public to even vote in its favour, let alone respond to its introduction by showing higher levels of trust and efficacy. In our most recent survey, just 35 per cent think that we should "change the voting system for general elections to the House of Commons to allow smaller political parties to get a fairer share of MPs", little different from the readings that have been obtained in response to this question on a number of occasions since 1983. Moreover, if it is the case that the current low level of trust and efficacy reflects a feeling that constitutional reform has not been sufficiently extensive, then we should find that trust and efficacy has fallen more over the last four years amongst the one-third or so who say they are in favour of changing the electoral system than it has amongst those who say they want to keep the system as it is. However, if anything the opposite is the case. For example, the percentage willing to trust governments at least most of the time fell by just three points between 1996 and 2000 among those in favour of electoral reform but by eight points amongst those wanting to keep the existing system.

Perhaps this is to take too narrow a view of the kinds of change to the political system that the public would like to see. After all, all the reforms we have considered so far are ones that still assume a framework of representative democracy in which parties compete at election time for the power to take decisions for the next four or five years. But perhaps what the public wants are more opportunities to participate in the process of decision making itself (Dalton, 1999: 74-77). After all, no less than 55 per cent disagreed and only 21 per cent agreed when we put the proposition to them that "even if I had the chance I would not be interested in having more say in government decisions". Moreover, as many as 40 per cent disagreed (although 43 per cent agreed) that, 
"between elections, the government should get on with running the country rather than bothering about public opinion".

One of the more participatory forms of decision making that has been introduced in recent years by some local councils is the 'citizens' jury'. Information pertinent to a decision that a local council has to make is presented to a small group of residents, sometimes selected at random, which is then invited to consider what decision they would make (Coote and Lenaghan, 1997). In order to tap attitudes towards this rather different kind of approach we asked our respondents how much they would trust the councillors on their local council to come to the "best view" about a proposed "major new building development in their neighbourhood" and how much they would trust "a jury of 12 ordinary local people chosen at random". The jury was clearly the more trusted device; nearly two-thirds said that they would trust this group to come to the best view "just about always" or "most of the time", whereas only one-third said the same of their local councillors.

But what matters for our purposes here is how people's views on these matters vary according to their trust in government or level of political efficacy. And there is some evidence to suggest that differences do exist. Among those who trust governments to put the interests of the nation first at least most of the time, nearly half (48 per cent) also trust local councillors to come to the best view about a planning development at least "most of the time", double the comparable figure among those who do not trust governments in this way (only 26 per cent of whom would trust local councillors in this way). By contrast, these two groups only differ by six percentage points in their views about the ability of a citizens' jury to come to the best view. So those with low levels of trust in government are almost as likely to trust a citizens' jury as are those with high levels of trust, but are much less likely to trust councillors to make the same decision. We find a similar pattern if we compare the attitudes of those with low and high levels of efficacy.

So we have found that Labour's programme of constitutional reform seems to have done little to increase people's confidence in their system of government. So far at least, those reforms have evidently had too little impact upon the public to be able to do so. Maybe over time they might have more success in increasing confidence. And it might be that more radical departures from the norms of representative democracy would be more successful. But, in truth, perhaps changing the way in which Britain is governed is simply not the right antidote to declining public trust and confidence. Perhaps the causes lie elsewhere, reflecting more fundamental and long-term changes in British society and government. It is to these questions that we now turn.

\section{What accounts for declining political trust?}

A wide range of explanations has been offered as to why people's confidence in how they are governed is falling, not just in Britain but in much of the developed world. Here we evaluate four of those explanations. ${ }^{6}$ 


\section{The relative capacity of governments}

The first of these explanations is that people no longer think governments can meet public needs and expectations. On the one hand, thanks to rising levels of education and personal affluence, people's expectations of what governments and politicians should achieve have increased. But, on the other hand, thanks to the process of globalisation, governments have lost much of their ability to influence the direction of their country's economy or to pursue distinctive social policies (Giddens, 1994). The resulting gap between what voters expect, and what they think governments can deliver, is held to produce negative attitudes towards political institutions. We might call this explanation the 'relative capacity' argument.

We have available to us two measures of whether people's expectations of politicians and government are rising or not. The first of these comprises what qualities people think it is important for MPs to have. As the next table shows, up to and including 1996 it did appear plausible to argue that expectations of MPs were rising. But now our latest survey has seen expectations fall back again. True, two qualities, "knowing about poverty" and being "independent minded", are still clearly more important to people now than when we first asked this question in 1983. But, so far as most of the other qualities are concerned, the picture now is little different to what it was in 1983.

Table 12 Expectations of MPs, 1983-2000

\begin{tabular}{lrrrr}
\hline \% who think it is important for MPs to ... & $\mathbf{1 9 8 3}$ & $\mathbf{1 9 9 4}$ & $\mathbf{1 9 9 6}$ & $\mathbf{2 0 0 0}$ \\
... be independent minded & 37 & 48 & 51 & 56 \\
... be well educated & 50 & 55 & 60 & 54 \\
... be from the local area & 48 & 60 & 61 & 54 \\
... be loyal to their party & 42 & 42 & 44 & 43 \\
$\ldots$ know about poverty & 27 & 41 & 45 & 42 \\
$\ldots$ have business experience & 22 & 30 & 34 & 28 \\
$\ldots$ have union experience & 14 & 13 & 14 & 14 \\
Base & 1761 & 2302 & 1180 & 2293 \\
\hline
\end{tabular}

Our second measure comprises people's views on what responsibilities governments should fulfil. In the following table we show the proportion of people who think that each of four possible responsibilities should "definitely" fall within the remit of government. Here the trends are almost the reverse of what we saw in Table 9.12. Thus, up to and including 1996, expectations of government appeared to be falling rather than rising. In each case the proportion saying the objective in question should definitely be the government's responsibility was lower than it was ten years earlier. But in our most recent survey that trend has been reversed; in all four cases the proportion saying the 
objective should definitely be the government's responsibility is now either at least as high or higher than it was in 1986.

Table 13 Expectations of government, 1986-2000

\begin{tabular}{lrrrr}
\hline \% who think it definitely should be the & & & & \\
government's responsibility to ... & 1986 & $\mathbf{1 9 9 0}$ & $\mathbf{1 9 9 6}$ & $\mathbf{2 0 0 0}$ \\
... provide health care for all & 84 & 84 & 81 & 87 \\
... provide a decent standard of living for the old & 80 & 77 & 70 & 80 \\
... keep prices under control & 52 & 47 & 40 & 64 \\
... provide a job for everyone who wants one & 30 & 23 & 26 & 39 \\
Base & 1321 & 1197 & 989 & 2008 \\
\hline
\end{tabular}

So neither of our measures easily substantiates the claim that there is a gradual, secular increase in people's expectations of politicians and government. Still, it is just about possible to argue that expectations appear to be at least a little higher now than they were in the 1980s. But what about people's perceptions of the ability of governments to deliver? Is there indeed a gap between what people think governments should do and what they think they are actually capable of delivering? Might this account for low levels of trust and efficacy?

In our 2000 survey, for the first time, we followed questions about what governments should do by ones that asked people how easy or difficult they thought it was for government to ensure that each objective was achieved. And indeed, there is a clear recognition that many objectives are not at all easy to deliver. Only 47 per cent think that it is easy for government to ensure that all old people have a decent standard of living (compared with 80 per cent who think that this is definitely government's responsibility), 42 per cent that it is easy to ensure that everyone has good access to adequate health care, and only 31 per cent that it is easy for governments to keep prices under control. Meanwhile, just 16 per cent think it is easy for government to ensure that everyone who wants a job has one.

But is this disjuncture responsible for low trust and efficacy? If it is, we should find lower levels of trust than average among those who believe that a particular objective should be the government's responsibility and who also think it difficult for the government to ensure that it happens. But this is not what we find. In the following table we illustrate this by showing the level of trust and efficacy among those who think that government should be responsible for ensuring that everyone who wants a job has one, broken down by whether they think that objective is easy or difficult for governments to fulfil. And, if anything, those whom it might be thought would be concerned about the relative incapacity of government (that is, who think it difficult for governments to ensure everyone has a job) are very slightly more trustful and efficacious than those who think it is easy. So, in practice then, it is those who think that it is 
easy for governments to deliver who are most likely to be disillusioned by their actual performance. It is thus perhaps good rather than bad news for governments that many people apparently recognise that in a number of respects politicians do not have an easy job.

Table 14 The impact of perceptions of government on trust and efficacy

\begin{tabular}{lcc}
\hline & \multicolumn{2}{c}{$\begin{array}{c}\text { Believe ensuring everyone } \\
\text { who wants a job has one is }\end{array}$} \\
$\begin{array}{lcc}\text { \% who trust governments just about always/most of the } \\
\text { time }\end{array}$ & $\begin{array}{c}\text { Easy } \\
\text { Difficult }\end{array}$ \\
$\begin{array}{lcc}\text { Base } \\
\text { \% with medium or high efficacy }\end{array}$ & 308 & 18 \\
Base & 28 & 30 \\
\hline
\end{tabular}

Table confined to those respondents who say that providing a job for everyone who wants one should "definitely" be the government's responsibility.

\section{Postmaterialism}

Our three remaining theories suggest, in different ways, that the decline in people's confidence in government is the result of wider social changes. The first of these theories is postmaterialism. Put forward by Ronald Inglehart (Inglehart, 1977, 1990, 1997; Abramson and Inglehart, 1995) it posits that the post-war experience of rising affluence, and continuous peace in the developed world, means that people have changed their priorities. Rather than seeking material security, which it would appear they can now largely take for granted, people are primarily concerned with developing their opportunities for selfexpression and involvement. One consequence of this is that they are less likely to take what governments do on trust and instead seek more opportunities to be involved in, and even to challenge, the decision-making process.

We included in our survey the most commonly used indicator of postmaterialism:

Looking at the list below, please tick a box next to the one thing you think should be Britain's highest priority, the most important thing it should do.

And which one do you think should be Britain's next highest priority, the second most important thing it should do? 


\author{
Maintain order in the nation \\ Give people more say in government decisions \\ Fight rising prices \\ Protect freedom of speech \\ Can't choose
}

People who say that maintaining order and fighting prices are their two highest priorities are classified as 'materialists' (that is, their primary concern is with economic and physical security). Those who opt for freedom of speech and greater involvement in decision making are 'postmaterialists'. Meanwhile, those who choose any other mixture are regarded as having 'mixed' orientations.

If a rise in postmaterialism is to account for the decline in people's confidence in how they are governed then we need to be able to demonstrate two things: that postmaterialists have lower levels of trust and efficacy than materialists, and that the proportion of postmaterialists in Britain has increased. However, while the first of these is only partly true, the second is not true at all. As the next table shows, postmaterialists are indeed less likely to trust governments to put the interests of the nation first at least most of the time. Just over one in ten postmaterialists falls into this category compared with as many as one in five materialists. But postmaterialists are little different in their level of system efficacy from materialists. ${ }^{7}$ And most importantly, only 12 per cent of people in Britain can be classified as postmaterialist, little different from the ten per cent who fell into that category in $1983 .{ }^{8}$

Table 15 Trust and efficacy by materialist/postmaterialist orientations, 2000

\begin{tabular}{lcccr}
\hline & $\begin{array}{c}\text { \% trust government } \\
\text { just about always } \\
\text { or most of the time }\end{array}$ & Base & $\begin{array}{c}\text { \% medium/high } \\
\text { efficacy }\end{array}$ & Base \\
Materialist & 20 & 402 & 29 & 402 \\
Mixed & 15 & 1081 & 32 & 1081 \\
Postmaterialist & 12 & 228 & 32 & 228 \\
\hline
\end{tabular}

\title{
Declining social trust?
}

An alternative claim as to how social change may be undermining people's confidence in how they are governed is that it reflects a decline in 'social trust'; that is, the degree to which people have trust in one another (Putnam, 1993, 2000). According to Putnam, in America at least, social trust is on the decline. And if we no longer have trust in each other then perhaps we should not be surprised that we do not trust in our politicians either.

Putnam's arguments are addressed more fully in the chapters by Johnston and Jowell and by Gardner and Oswald. Here we simply have to address the same 
two arguments that we did in respect of postmaterialism: are those with low levels of social trust less likely to trust governments or to have high levels of efficacy, and has social trust declined in Britain in recent years? We also follow the same strategy as we did in respect of postmaterialism by deploying the most commonly used simple indicator of social trust:

Generally speaking, would you say that most people can be trusted, or that you can't be too careful in dealing with people?

Whether or not there is a link at all between social and political trust is the subject of some dispute. A number of studies have suggested that those who are willing to trust other individuals are no more or less trusting of governments than anyone else (Jackman and Miller, 1998; Newton, 1999; Newton and Norris, 2000). However, this claim is disputed by Hall (1999: 454), while others have suggested that, although such a relationship may exist, it is political trust that helps generate social trust rather than the other way around (Levi and Stoker, 2000). ${ }^{9}$ In fact, our latest survey suggests that there is some relationship between social and political trust. Among those who say that "most people can be trusted", one in five trust governments to put the interests of the nation first at least most of the time. But this figure falls to one in eight amongst those who believe that you cannot be too careful in your dealings with other people. And there appears to be an even stronger relationship with political efficacy (see also Johnston and Jowell, 1999). As many as 38 per cent of the trustful have a medium or high level of efficacy on our scale, compared with just 24 per cent of the not so trustful.

However, as in the case of postmaterialism, there is no clear evidence that levels of social trust have declined in Britain over time. As Johnston and Jowell show in Table 8.5, the level of social trust measured by the British Social Attitudes survey on three occasions between 1997 and 2000 mirrors that obtained by the World Values Survey in 1981 and 1990 - with around 45 per cent being 'trustful'. Again it appears that British society has simply not changed to the extent that has been claimed.

\section{The decline of party identification}

So far we have cast doubt on two of the wider social changes that might be helping to undermine people's confidence in the way they are governed. But there is a further change within British society which remains worthy of exploration. This is the gradual and persistent decline in strength of attachment to political parties (Crewe and Thomson, 1999). According to party identification theory (Budge et al., 1976), those who have a strong attachment to a political party are not only more likely to remain loyal to that party in the polling booth, but are also more likely to support the political system. After all, they identify with a party that plays according to the rules of electoral competition in their country and this should help ensure their own respect for and trust in those rules (Barry, 1970; Crewe et al., 1977). And if this is the case, 
and if levels of party identification have declined, there would be good reason to expect levels of political trust to decline as well.

The table below confirms that there has indeed been a gradual and persistent decline in attachment to political parties over the last few decades. Whereas in 1987, 46 per cent said they felt "very" or "fairly" strongly attached to the party they supported, now only 32 per cent feel that way. Moreover, as in the case of trust and efficacy, strength of identification weakened notably in the mid-1990s (though equally there was no sign of any recovery in the immediate wake of Labour's election to office in 1997).

Table 16 Trends in strength of party identification, 1987-2000

\begin{tabular}{lrrrrr}
\hline Strength of party identification & $\mathbf{1 9 8 7}$ & $\mathbf{1 9 9 3}$ & $\mathbf{1 9 9 6}$ & $\mathbf{1 9 9 8}$ & $\mathbf{2 0 0 0}$ \\
Very strong & 11 & 9 & 9 & 8 & 6 \\
Fairly strong & 35 & 33 & 28 & 28 & 26 \\
Not very strong & 40 & 44 & 47 & 48 & 49 \\
No party identification & 8 & 10 & 10 & 11 & 13 \\
Base & 2847 & 2945 & 3620 & 3145 & 3426 \\
\hline
\end{tabular}

Meanwhile, we can also see in the next table that those with a strong party identification are more likely to have high levels of trust both in government and in system efficacy. For example, nearly three in ten of those with a "very strong" party identification trust governments just about always or most of the time, compared with just one in twelve of those who do not identify with a party at all. At last then, we seem to have a plausible explanation as to how long-term changes among the British public have served to undermine confidence in the country's political system.

Table 17 Trust and efficacy by strength of party identification, 2000

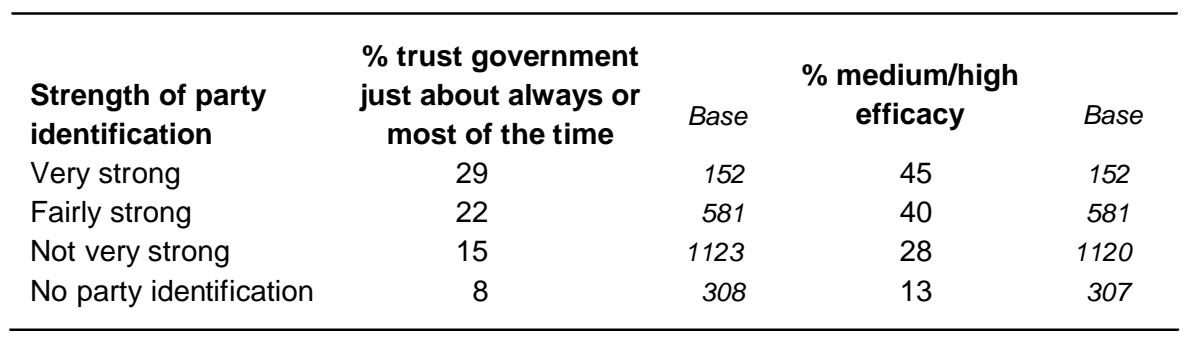

However, if this decline in party identification accounts for falling confidence in government we should not expect to find any changes in levels of trust and 
efficacy among those with a strong party identification; there is no reason these should not be as high now within this group as they ever were. But, as the following table shows, this is not what we find. The proportion of strong identifiers who trust governments at least just about always has fallen from nearly a half in 1987 to under a third now. A similar decline has occurred amongst all of the other levels of identification as well. ${ }^{10}$

Table 18 Trends in strength of party identification and trust in government, 1987-2000

\begin{tabular}{lrrrrrrrr}
\hline $\begin{array}{l}\text { Strength of party } \\
\text { identification }\end{array}$ & \multicolumn{10}{c}{$\%$ trust government just about always/most of the time } \\
& $\mathbf{1 9 8 7}$ & Base & $\mathbf{1 9 9 6}$ & Base & $\mathbf{1 9 9 8}$ & Base & $\mathbf{2 0 0 0}$ & Base \\
& 48 & 188 & 25 & 106 & 34 & 153 & 29 & 152 \\
Very strong & 43 & 483 & 22 & 321 & 33 & 584 & 22 & 581 \\
$\quad \begin{array}{l}\text { Fairly strong } \\
\text { Not very strong }\end{array}$ & 33 & 566 & 23 & 569 & 26 & 989 & 15 & 1123 \\
$\quad \begin{array}{l}\text { No party } \\
\quad \text { identification }\end{array}$ & 14 & 93 & 19 & 110 & 21 & 241 & 8 & 308 \\
All & 37 & 1410 & 22 & 1173 & 28 & 2071 & 16 & 2293 \\
\hline
\end{tabular}

So, at most, falling party identification can only account for part of the decline in trust and efficacy we have seen in recent years. Britain does indeed now have fewer strong party identifiers who are encouraged by their enthusiasm into having confidence in how they are governed. But, even among strong party identifiers, their enthusiasm for their party seems less likely now to translate into trust in how they are governed.

\section{Conclusions}

Three key findings have emerged from this study. First, the decline in confidence in how we are governed that emerged during the last Conservative government has not been reversed during Labour's first term of office. In particular, Labour's programme of constitutional reform appears to have done little or nothing to reverse that decline. Second, although that decline in confidence may have depressed turnout at recent elections, its role should not be exaggerated. Moreover, it appears to have had little impact on the public's willingness to engage in other forms of political participation. And third, falling confidence does not appear to be primarily the product of irreversible social changes or forces such as globalisation. Labour's attempts to reverse that decline may so far have failed but they cannot be accused of having engaged in a Canute-like attempt to stop an irreversible tide of social change. Britain's democracy may have something of a problem securing the support of its citizens, but it apparently does not face a fundamental crisis. 
Constitutional reform might not have been the right remedy for the recent decline in confidence in government, but that does not mean that it is no remedy at all. Equally, while restoring confidence in government might make some contribution to improving electoral turnout, it is unlikely to be a sufficient remedy on its own. Rather, in order to understand recent trends in confidence and participation we probably have to look at other political developments in recent years. Do governments deliver on their promises? Do politicians avoid accusations of sleaze? And does there seem to be much to choose between the parties? Arguably the answers to those questions has been 'no' for too many voters under both the Conservative and Labour administrations in recent years to encourage voters to go to the polls or to have much confidence in how they are governed. If so, the future health of Britain's democracy probably depends on whether or not this must always be so.

\section{Notes}

1. Moreover, turnout in 1918 was reduced by the circumstances of war combined with a threefold expansion in the size of the electorate. In practice the level of voluntary abstention was higher in 2001 than at any time since the advent of the mass franchise.

2. We may also note that there is no evidence that reported interest in politics has declined either. One in three say that they have a great deal or quite a lot of interest in politics, a figure that was virtually unchanged from when we first asked this question in 1986.

3. Our latest reading is also confirmed by the latest State of the Nation survey conducted by ICM in autumn 2000. This found just 31 per cent saying that the system could not be improved or could only be improved in small ways (see www.icmresearch.co.uk).

4. Political efficacy is here measured using a Likert scale based on the first three items in Table x.4. In each case the component items are scored from $1=$ "Strongly agree" = low efficacy to $5=$ "Strongly disagree" = high efficacy. Those classified as having low efficacy are those with an average rounded score across all three items of 1or 2, those as having high efficacy are those with an average score of 4 or 5 while those with an average score of 3 are those deemed to have medium efficacy. The scale has a Cronbach's alpha of 0.66 .

5. Moreover, we should note that the proportion who say that "It is everyone's duty to vote", is at 64 per cent no different now from what it was in 1996, and is only four points lower than it was in 1991 and 1994. So there appears so far at least to be little undermining of the sense that voting is a civic duty. See also Electoral Commission (2001).

6. The range of explanations is discussed extensively in Norris (1999), Levi and Stoker (2000) and Pharr and Putnam (2000).

7. The table in fact rather understates the impact of postmaterialism on trust in government. Postmaterialists tend to be highly educated and those with a degree tend to have higher levels of trust. The low level of trust amongst postmaterialists is thus even more remarkable given their educational level. However, multivariate analysis of the relationship between educational attainment, postmaterialism and 
system efficacy indicates that the absence of any bivariate association between the last two is not the result of the potentially confounding impact of educational attainment.

8. The latter figure comes from the 1983 British Election Study.

9. Moreover, Newton and Norris (2000) suggest that while there may be no relationship at the individual level, governments are able to perform more effectively in societies with high levels of social trust and as a result are able to secure a higher level of political trust.

10. Equally when the level of trust in government rose in 1998, it rose amongst each group of identifiers.

\section{References}

Abramson, P. and Inglehart, R. (1995), Value Change in Global Perspective, Ann Arbor: University of Michigan Press.

Almond, G. and Verba, S. (1963), The Civic Culture; Political Attitudes and Democracy in Five Nations, Princeton, NJ: Princeton University Press.

Barnett, A. (1993), Debating the constitution: new perspectives on constitutional reform, Cambridge: Polity Press.

Barry, B. (1970), Sociologists, Economists and Democracy, London: CollierMacmillan.

Blair, A. (1996), 'Democracy's second age', The Economist, 14 September 1996.

Budge, I., Crewe, I. and Farlie, D. (eds.) (1976), Party Identification and Beyond, New York: Wiley.

Coote, A. and Lenaghan, J. (1997), Citizens' Juries: Theory into Practice, London: IPPR, 129-190.

Crewe, I., Särlvik, B. and Alt, J. (1977), 'Partisan Dealignment in Britain 1964-74', British Journal of Political Science, 7: 129-90.

Crewe, I. and Thomson, K. (1999), 'Party loyalties: dealignment or realignment?' in Evans, G. and Norris. P. (eds.), Critical Elections - British Parties and Voters in Long-Term Perspective, London: Sage.

Curtice, J. (2001, forthcoming), 'Devolution and Democracy: New Trust or Old Cynicism' in Curtice, J., McCrone, D., Park, A. and Paterson, L. (eds.), New Scotland, New Society? Are Social and Political Ties Fragmenting?, Edinburgh: Edinburgh University Press.

Curtice, J and Jowell, R (1995), 'The sceptical electorate' in Jowell, R., Curtice, J., Park, A., Brook, L., and Ahrendt, D. (eds.), British Social Attitudes: the $12^{\text {th }}$ Report, Aldershot: Dartmouth.

Curtice, J. and Jowell, R. (1997), 'Trust in the Political System' in Jowell, R., Curtice, J., Park, A., Brook, L., Thomson., K, and Bryson, C. (eds.), British Social Attitudes: the $14^{\text {th }}$ Report - The end of Conservative values?, Aldershot: Ashgate.

Dalton, R. J. (1999), 'Political Support in Advanced Industrial Democracies' in Norris, P., Critical Citizens: Global Support for Democratic Governance, Oxford: Oxford University Press. 
Davis, R. and Curtice, J. (2000), 'Speaking for the Public: representation and audience participation during the 1997 British general election campaign', Harvard International Journal of Press/Politics, 5: 62-77.

Electoral Commission (2001), The Official Results, London: Politicos.

Fuchs, D. and Klingemann, H. D. (1995), 'Citizens and the State: A Changing Relationship?' in Klingemann, H. D., and Fuchs, D., Citizens and the State, Oxford: Oxford University Press.

Giddens, A. (1994), Beyond Left and Right, Cambridge: Polity Press.

Hall, P. (1999), 'Social Capital in Britain', British Journal of Political Science, 29: 417461.

Hardin, R. (2000), 'The Public Trust' in Pharr, S. J. and Putnam, R. D. (eds.), Disaffected Democracies: What's Troubling the Trilateral Countries?, Princeton, NJ: Princeton University Press.

Heath, A. F. and Taylor, B. (1999), 'New Sources of Abstention?' in Evans, G. and Norris. P (eds.), Critical Elections - British Parties and Voters in Long-Term Perspective, London: Sage.

Holden, A. (ed.) (2001), Unlocking the Policies, London: Charter88.

Inglehart, R. (1977), The Silent Revolution: Changing Values and Political Styles, Princeton, NJ: Princeton University Press.

Inglehart, R. (1990), Culture Shift in Advanced Industrial Society, Princeton, NJ: Princeton University Press.

Inglehart, R. (1997), Modernization and Postmodernization: Cultural, Economic and Political Change in 43 Societies, Princeton, NJ: Princeton University Press.

Jackman, R. W and Miller, R. A. (1998), 'Social Capital and Politics', Annual Review of Political Science, 1: 47-73.

Johnston, M. and Jowell. R. (1999), 'Social Capital and the Social Fabric' in Jowell, R., Curtice, J., Park., A. and Thomson., K. (eds.), British Social Attitudes: the $16^{\text {th }}$ Report - Who shares New Labour values?, Aldershot: Ashgate.

Klingemann, H. D. (1999), 'Mapping political support in the 1990s; a global analysis' in Norris, P., Critical Citizens: Global Support for Democratic Governance, Oxford: Oxford University Press.

Levi, M. and Stoker, L. (2000), 'Political Trust and Trustworthiness', Annual Review of Political Science, 3: 475-507.

Marsh, A. (1977), Protest and Political Consciousness, Beverley Hills: Sage.

Newton, K. (1999), 'Social and Political Trust in Established Democracies' in Norris, P., Critical Citizens: Global Support for Democratic Governance, Oxford: Oxford University Press.

Newton, K. and Norris, P. (2000), 'Confidence in Public Institutions: Faith, Culture or Performance?' in Pharr, S. J. and Putnam, R. D. (eds.), Disaffected Democracies: What's Troubling the Trilateral Countries?, Princeton, NJ: Princeton University Press.

Norris, P. (1999), 'Introduction: The Growth of Critical Citizens?' in Norris, P., Critical Citizens: Global Support for Democratic Governance, Oxford: Oxford University Press.

Pattie, C. and Johnston, R. (2001a), 'Losing the Voters' Trust: Evaluations of the Political System and Voting at the 1997 British General Election', British Journal of Politics and International Relations, 3: 191-222. 
Pattie, C. and Johnston, R. (2001b), 'A Low Turnout Landslide: Abstention at the British General Election of 1997', Political Studies, 49: 286-305.

Pharr, S. J. and Putnam, R. D. (eds.) (2000), Disaffected Democracies: What's Troubling the Trilateral Countries?, Princeton, NJ: Princeton University Press.

Putnam, R. D. (2000), Bowling Alone - the collapse and revival of American community, New York: Simon \& Schuster.

Putnam, R. D. (1993), Making Democracy Work: Civic Traditions in Modern Italy, Princeton NJ: Princeton University Press.

\section{Acknowledgements}

Most of the questions reported in this chapter were financed by a grant from the Economic and Social Research Council (grant no. L215252032) as part of its Democracy and Participation Programme. 